\title{
4
}

\section{How do Mesenchymal Stem Cells Repair?}

\author{
Patricia Semedo, Marina Burgos-Silva, \\ Cassiano Donizetti-Oliveira and Niels Olsen Saraiva Camara \\ Federal University of São Paulo (UNIFESP), University of São Paulo (USP) \\ Brazil
}

\section{Introduction}

Mesenchymal stem cells' field has flourished lately. It is undoubted that MSC have the ability to repair several damaged tissues. Multipotent mesenchymal stromal cells (MSC) can be isolated and efficiently expanded from almost every single body tissue and has the ability of self-renewal and differentiation into various mesodermal cell lineages. MSC can provide effective treatments for a wide range of diseases and posses several applications in regenerative medicine such as tissue repair and gene delivery. In fact, relevant data have been generated in animal models of human diseases and some clinical trials are even being started. However, little is known about how MSC can repair. It is suggested that the MSC has pleiotropic actions releasing pro-survival factors to cytoprotective microvesicles. In this chapter, we will review and discuss the main conjectures on the mechanisms of action of MSC in animal and human contexts.

\section{Mesenchymal Stem Cells (MSC) biology: concept, terminology, sources, cell phenotype, gene profile and senescence}

The so called "stem cell" called "stem cell" is the cell that by definition has two main properties: 1) Asymmetric division and 2) Differentiation capacity. Not all cells in our body follow these two properties.

In this sense, there are two main cells: embryonic stem cells and adult stem cells. For the purpose of this chapter, we will focus on adult stem cells.

The existence of adult stem cell is now well accepted. Tissue repair after injury and also the continuous homeostatic self renewal of some tissue consolidate this idea (1).

In 1970, Friendstein and collaborators described for the first time that bone marrow harbours not only hematopoetic stem cells (HSC), but also other type of cell that has clonogenic properties in vitro, characterizing these cells by their property to form fibroblast colonies in the primary passage in culture (CFU-F: colony-forming unit fibroblastic)(2). Later on, therapeutic approaches were approaches were achieved by using these cells in bone disorders $(3,4)$.

Years later, Caplan and co-workers named these cells as mesenchymal stem cells (MSC) (5, 6). In 1999, Pittenger et al demonstrated that these cells are multipotent stem cells with potential to differentiate into other cells from mesenchymal tissues (7).

Others sources of mesenchymal stem cells have been described since then. MSC are not only found at bone marrow. Adipose tissue has also been demonstrated as a potential niche (8). In addition, dental pulp (9), limbus (10), amniotic membrane (11) amniotic fluid (12), kidney 
(13) and several other organs may harbor mesenchymal stem cell populations. In culture, all these cells posses a fibroblast-like phenotype and share similarities in their immunophenotype and differentiation assays.

Once it was seen that, several organs and tissue have MSC, the name needed to be standardized. In 2005, the International Society of Stem Cell Research (ISSCR) termed these cells as multipotent mesenchymal stromal cells for fibroblast-like plastic adherent cells isolated from any organ (14). And if this cell follows the minimal criteria of stem cell, so this cell can be called mesenchymal stem cell. There are three main criteria in order to determine the indentity of MSC: 1) must have adherence to plastic; 2) expression of CD105, CD73 and CD90, and lack of expression of CD45, CD34, CD14 or CD11b, CD79alpha or CD19 and HLA-DR surface molecules; 3) must have differentiation potential (15). More recently, Caplan has suggested, due to its properties; to again rename MSC to "Medicinal Signaling Cells" because of its main mechanism of action (16).

Despite this phenotype similarity, gene profile among all these cells may be different. A molecular signature of markers of stem lineage markers and genes regulating developmental and regenerative processes is more elucidative (17). Peroni et al, in a detailed work, demonstrated that MSC from bone marrow have an identical molecular profile when compared to MSC from adipose tissue. Nevertheless, a difference in some genes expression may happen with culture conditions (17). However, some authors suggest that the site of origin of MSC leads to the expression of specific genes pathways. A comparative study of MSC from bone marrow and MSC from umbilical cord from Panepucci et al showed that there are some gene that are more expressed in one cell than another. For instance, genes related to antimicrobial activity and osteogenesis are more expressed in MSC from bone marrow; and genes related to matrix remodeling and angiogenesis are more expressed in MSC from umbilical cord (18). Proteome analysis of MSC also demonstrated a full list of proteins expressed by MSC as described by Park et al (19).

In fact, MSC population is not spread all over the organ. To maintain its properties, stem cells are located at niches. Niche is an environment defined by extracellular matrix and others cells that secrete several factors to maintain stem cells under its undifferentiated state and quiescence, since adult stem cells are highly sensitive to external signals (20-22). Thus, if the niche is not well regulated, for instance in a pathologic state, stem cells may not react as expected: to repair and maintain homeostasis. Moreover, a problem in this delicate balance between stem cells and its niche may also lead to cancer (23).

The niche per se is very important; however stem cell stability is also necessary. DNA damage in melanocyte stem cells induce premature differentiation, leading to apoptosis and senescence (24). Regarding that cellular aging may be due to DNA alterations; this is probably an explanation for the inverse correlation between age and adult stem cell population and its functionality (25).

Despite all efforts, the potential niche for adult stem cell in vivo has not yet been defined. A perisvascular niche is one possible place $(26,27)$. Some authors support the idea that mesenchymal stem cells are located throughout the body as pericytes, since it is related to tissue homeostasis and blood vessels stabilization (27). In this sense, da Silva Meirelles et al showed the direct correlation between the quantity of blood vessel and stem cells (28).

\section{MSC therapy and its ability to repair several diseases}

As previously written, all tissues per se have the capacity of homeostasis maintenance. However, after an injury, this process is somehow disturbed by inflammation or by extracellular matrix disruption, not allowing proper stem cell action. 
Thus, in a way to assist the repair process, several works have focused on the administration of exogenous stem cells. Surprisingly, the administration of adult stem cell in several experimental diseases have showed to improve in its clinical outcome and moreover amelioration of tissue architecture.

However, the mechanism of action that leads to this improvement is not well defined. Fusion of dying cells with MSC, differentiation of MSC to other cell types or paracrine action, by secretion of several bioactive factors are the main mechanism of action suggested. New mechanisms have also been suggested with the knowledge of microRNA. These topics will be better explained in the next sections.

\subsection{Animals models of human diseases: kidney, heart, CNS, liver, lung and pancreas} The main experimental models treated with mesenchymal stem cells are summarized in the next table (Table I).

\begin{tabular}{|c|c|c|c|c|}
\hline & $\begin{array}{l}\text { Experimental } \\
\text { Model }\end{array}$ & $\begin{array}{c}\text { Cell } \\
\text { (amount/way/time) }\end{array}$ & \begin{tabular}{|c|} 
Mechanism of Action \\
suggested for better \\
outcome of injury
\end{tabular} & Reference \\
\hline \multirow{7}{*}{ Kidney } & \multirow{3}{*}{ Acute Kidney Injury } & $\begin{array}{l}\text { Rat MSC, } 2 \times 10^{5} \text { cell/ rat, } \\
\text { e.v., } 6 \text { h after ischemia- } \\
\text { reperfusion injury }\end{array}$ & Immunomodulation & (29) \\
\hline & & $\begin{array}{l}\text { Microvesicles from } \\
\text { human MSC, } 15 \\
\mu \mathrm{g} / \text { animal, e.v., } 3 \text { days } \\
\text { after glycerol } \\
\text { administration } \\
\end{array}$ & $\begin{array}{l}\text { mRNA and microRNA } \\
\text { carried by } \\
\text { microvesicles }\end{array}$ & (30) \\
\hline & & $\begin{array}{l}\text { MSC, } 1 \times 10^{5} \text { cell/mouse, } \\
\text { intra-arterially, } 30 \text { min } \\
\text { after inschemia- } \\
\text { reperfusion injury }\end{array}$ & $\begin{array}{l}\text { Paracrine action - } \\
\text { VEGF, HGF, IGF-1 } \\
\text { secretion }\end{array}$ & (31) \\
\hline & \multirow[t]{2}{*}{$\begin{array}{l}\text { Chronic Kidney } \\
\text { Injury (remnant } \\
\text { model) }\end{array}$} & $\begin{array}{l}\text { Rat MSC, } 2 \times 10^{5} \text { cell } / \text { rat, } \\
\text { e.v., } 2^{\text {nd }} \text { week after } 5 / 6 \\
\text { remnant model every } \\
\text { other week until } 8^{\text {th }} \\
\text { week. }\end{array}$ & $\begin{array}{l}\text { Immunomodulation } \\
\text { and paracrine action }\end{array}$ & (32) \\
\hline & & $\begin{array}{l}\text { Rat MSC, } 1 \times 10^{5} \text { cell } / \text { rat, } \\
\text { e.v., } 1 \text { week after } 5 / 6 \\
\text { nephrotomy }\end{array}$ & $\begin{array}{l}\text { MSC engraftment and } \\
\text { paracrine action }\end{array}$ & (33) \\
\hline & $\begin{array}{l}\text { Chronic Kidney } \\
\text { Injury (unilateral } \\
\text { ureteral obstruction) }\end{array}$ & $\begin{array}{l}\text { Human MSC, } 1 \times 10^{6} \\
\text { cell/rat, intra-arterially, } \\
\text { after ureter obstruction }\end{array}$ & Immunomodulation & (34) \\
\hline & Glomerulonephritis & $\begin{array}{l}\text { Rat MSC, } 2 \times 106 \\
\text { cell/rat, intra-arterially, } \\
2 \text { days after Thy1.1 } \\
\text { administration }\end{array}$ & $\begin{array}{l}\text { Early results: paracrine } \\
\text { effect } \\
\text { Long-term results: } \\
\text { maldifferentiation of } \\
\text { MSC to adipocytes }\end{array}$ & (35) \\
\hline & & & & \\
\hline
\end{tabular}




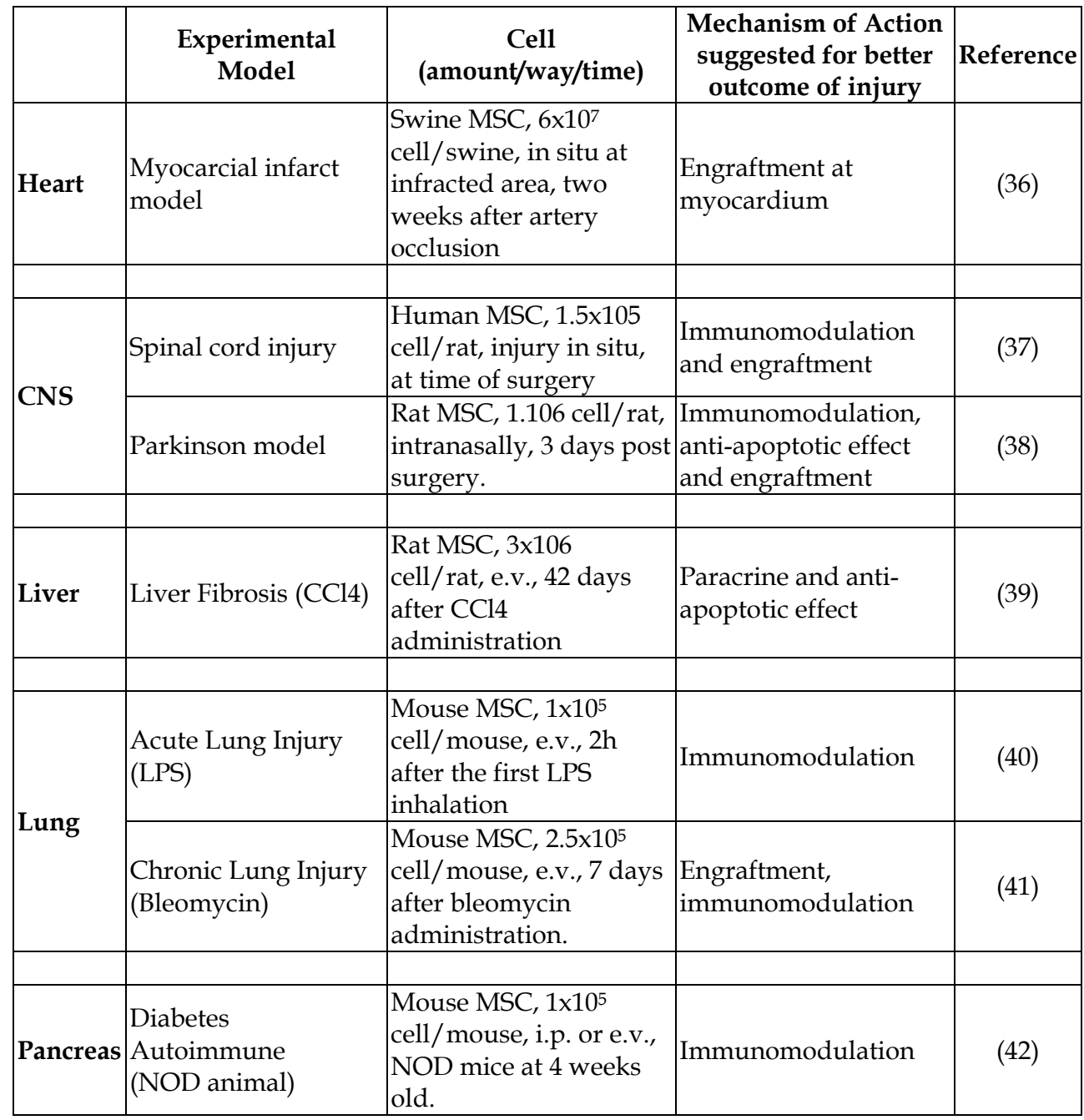

Table I. Some pre-clinical data on MSC therapy

\subsection{Human trials with MSC}

Pre-clinical studies have stimulated human clinical trials. Searching for "adult stem cell" at Clinicalstrials.gov, nearly 3300 studies were found. Within these studies, 1530 are recruiting patients. Some of these clinical trials are related in Table II.

These numbers are alarming. The real mechanism of action of MSC, as well as the long-term studies are not yet clarified. Despite it, others issues still hold doubts such as the amount of cells, site of injection, which cell is the best for each illness, which is the level of cell survival and engraftment, etc. These questions should be answered before clinical trials are started.

However, completed clinical trials have demonstrated efficient amelioration on clinical outcomes. MSC therapy has been focused on graft versus host diseases (GvHD) (43), limb 
ischemia (44), acute kidney injury (45), lung injury (46), myocardial infarction (47), etc. Safety and efficacy will be discussed next in this article. How MSC leads to this better clinical outcome, despite which disease is it, is described below.

\begin{tabular}{|c|c|c|}
\hline Study & Condition & Status \\
\hline $\begin{array}{l}\text { Evaluation of Circulating Levels of } \\
\text { Adult Stem Cells in the Peripheral } \\
\text { Blood of Patients With Acute } \\
\text { Decompensated Heart Failure and } \\
\text { Following Stabilization, in } \\
\text { Comparison With Healthy } \\
\text { Volunteers NCT01027403 }\end{array}$ & Heart Failure & Recruiting \\
\hline $\begin{array}{l}\text { Adult Stem Cell Therapy in Liver } \\
\text { Insufficiency NCT00147043 }\end{array}$ & Liver Cirrhosis & Completed \\
\hline $\begin{array}{c}\text { Safety Study of Adult Stem Cells to } \\
\text { Treat Patients With Severe Leg } \\
\text { Artery Disease NCT00913900 }\end{array}$ & Critical Limb Ischemia & Recruiting \\
\hline $\begin{array}{l}\text { Long-term Safety and Efficacy of } \\
\text { Adipose-derived Stem Cells to Treat } \\
\text { Complex Perianal Fistulas in Patients } \\
\text { Participating in the FATT-1 } \\
\text { Randomized Controlled Trial } \\
\text { NCT01020825 }\end{array}$ & Complex Perianal Fistula & Recruiting \\
\hline $\begin{array}{l}\text { Evaluation of PROCHYMAL[tm] } \\
\text { Adult Human Stem Cells for } \\
\text { Treatment-resistant Moderate-to- } \\
\text { severe Crohn's Disease } \\
\text { NCT00482092 }\end{array}$ & Crohn's Disease & Recruiting \\
\hline $\begin{array}{l}\text { Autologous Mesenchymal Stem } \\
\text { Cells From Adipose Tissue in } \\
\text { Patients With Secondary Progressive } \\
\text { Multiple Sclerosis NCT01056471 }\end{array}$ & Multiple Sclerosis & Recruiting \\
\hline $\begin{array}{c}\text { Mesenchymal Stem Cell Infusion as } \\
\text { Prevention for Graft Rejection and } \\
\text { Graft-Versus-Host Disease } \\
\text { NCT00504803 }\end{array}$ & Hematological Malignancies & Recruiting \\
\hline $\begin{array}{l}\text { Intravenous Stem Cells After } \\
\text { Ischemic Stroke NCT00875654 }\end{array}$ & Stroke & Recruiting \\
\hline $\begin{array}{l}\text { Induction Therapy With Autologous } \\
\text { Mesenchymal Stem Cells for Kidney } \\
\text { Allografts NCT00658073 }\end{array}$ & Renal Transplant Rejection & Completed \\
\hline
\end{tabular}

Table II. Some clinical trials ongoing 


\section{MSC mechanisms of action}

\subsection{Differentiation}

Before talking about differentiation it is important to consider the two categories into which stem cells can be classified (according to their developmental status): embryonic and adult (postnatal). Each represents a diverse differentiation potential status and a different potential application. Embryonic stem are pluripotent cells isolated from the inner cells mass of blastocysts, and are capable of giving rise to cells found in all three germ layers of the embryo. They are considered to have the greatest range of differentiation potential. On the other hand, adult stem cells have the capacity renew tissue after trauma, disease, or aging. These cells are found in different scales of quantity and potentiality (uni-, di-, tri-, and multi-potent), and their differentiation status is related to cell plasticity, where cells of one type give rise to cells of another type, however closely related (cell flexibility) (48). Mesechymal stem cells are adult stem cells with reduced differentiation capacity and higher plasticity capacity.

The differentiation and plasticity characteristics mentioned above exemplify the flexibility of MSC. It is well known that mesenchymal cells can shift from one differentiation pathway to another under modified external conditions, and can shift from quiescence to a proliferative state or that MSC differentiation can be reversed at least up to a certain stage $(49,50)$. MSCs have also been reported to differentiate into various epithelial cell types after systemic administration in vivo. Studies have shown that after bleomycin exposure, MSC lung engraftment was enhanced showing a small percentage of MSC localized to areas of lung injury. In addition, MSC also differentiated into type I pneumocytes (51) or assumed phenotypic characteristics of all major cell types in lung including fibroblasts, type I and type II epithelial cells, and myofibroblasts (52). MSCs have also been shown to differentiate into retinal pigment epithelial cells (53), skin epithelial cells (54) and tubular epithelial cells in kidney (55).

Different techniques have been used for MSC differentiation: use of biological and pharmacological reagents (56-59); mechanical cues (60-62) and external mechanical and electrical forces (63-66). Both mechanical and electrical stimulation have been applied separately and combined with soluble factors to facilitate MSC differentiation (67).

The criteria for differentiation need to be rigorously defined. It appears difficult to ascertain about differentiation process. Some markers are specific for certain cells; however they do not have functional relation. In addition these markers are not unique to characterize a specific cell. Delorme et al have found that MSC express cytoskeletal proteins usually expressed in neural stem cells (nestin), hepatocytes (cytokeratin-8 and -18), biliary cells (cytokeratin-19), and sarcomeric muscle (troponins, a-C-actin), without the expression of proneural or neuronal, prohepatocytic, or myogenic key transcription factors (68). Although cytoskeletal markers remain adequate indicators of a differentiation pathways, there are numerous exceptions to the rule, such as the expression of cytokeratin-18 in vascular smooth muscle cells in the synthetic phase and other similar misleading expression factors as reported by Montzka (69).

Some of the observed differentiations may also result from reprogramming. Dezawa and colleagues have shown that rodent and human bone marrow MSC can be reprogrammed into cells with skeletal muscle potential after specific treatment comprising first cytokines and then gene transfer of the notch intracellular domain (70).

Differentiation induction can be also marked by the decline of one factor at the expense of the other, like runt-related transcription factor-2 (RUNX2) downregulation and peroxisome 
proliferator-activated receptor-g (PPAR $\gamma$ ) upregulation in the adipogenic condition, which remains to be tested at the single cell level (71).

It has been shown that MSC of various species may undergo myogenic differentiation $(72,73)$. In a mouse model of myocardial infarction it has been seen that MSCs are capable of engrafting in the site of injury and differentiating into cardiomyocyte-like cells expressing typical cardiomyocyte markers (74). Another study showed that in mice undergoing cisplatin-mediated acute renal failure, systemic injection of MSCs resulted in accumulation of MSC in the kidney and differentiation into tubular epithelial cells that exhibited the characteristic brush border of the proximal tubule cells (55). Besides, there have been a number of reports suggesting that MSC differentiate into epidermal keratinocytes and endothelial cells in vivo $(75,76)$. In vivo, adipose-derived MSC can migrate through the hemato-encephalic barrier after adhesion to the endothelium (77), and they can differentiate into neuroglial lineages after intraventricular in utero injection in rats (78). However, in humans there is no evidence concerning the neural regenerative potential of MSC.

MSC obtained from different tissue sources show some differences regarding differentiation potential and gene expression profiles. Thus, it has become clear that the microenviroment in which MSCs are transplanted, growth factors and local cellular interactions, play a pivotal role in determining both MSC biology (survival, proliferation, and specific differentiation) and eventually a clinical measurable improvement.

\subsection{Fusion}

Cell fusion is a process that has an important biological role in the development, physiology and disease of multicellular organisms. For example, we have the zygote formation and organogenesis of various tissues, such as placenta, bone and skeletal muscle. There are different types of cell fusion: homotypic and heterotypic cell fusion. Homotypic fusion happens between cells of the same type; like fusion between myoblasts for the formation and growth of multinuclear myofibres and multinucleated cells during chronic inflammatory conditions. In a heterotypic cell fusion, which describes the fusion between cells of different lineages, we have stem cells, where in specific adult stem cells can be used for clinical therapy by introducing a nuclei or functional genes in aged or degenerating cells (79). Recent reports have indicated that stem cells can fuse with differentiated cells in a range of tissues, including the brain, kidney, heart, lung and liver.

It's known that inflammation promotes migration and infiltration of bone marrow-derived stem cells to sites of tissue injury. Moreover, inflammation also increases the frequency of stem cell fusion. In the brain, chronic inflammation cen cause an increase in spontaneous fusion events through the increase of cytokine levels, by activating immune cells or by damaging the blood brain barrier leading to increased permeability $(80,81)$. Mechanistically, it is important to note that lipid bilayer membranes do not spontaneously fuse, and that fusion between membranes involves a highly intricate choreography of lipids and proteins. Alterations in the cell membrane that are likely to occur during chronic inflammation and the concomitant production of a variety of cytokines may predispose certain cells to fusion events.

Scolding et al hypothesized that endogenous factors associated with inflammation, such as tumour necrosis factor (TNF)-alpha and interferon (IFN)-gamma, may also directly activate stem cells and Purkinje cells to promote fusion. They demonstrated that fusion 
between MSCs and cerebellar neurons can occur spontaneously in vitro, associated with a markedly higher incidence of the inflammatory mediators such as TNF-alpha and IFNgamma. The same group, has shown that human bone marrow-derived MSC also exhibit this potentially reparative action in vivo, fusing with Purkinje cells in the rodent cerebellum. These function events are also increased in the neuroinflammatory environment of experimental autoimmune encephalomyelitis (EAE), with no apparent loss in Purkinje cell numbers (82).

To confirm this, previous reports have demonstrated fusion between rodent haematopoietic stem cells and rodent Purkinje cells, with increased levels occurring in the context of central nervous system (CNS) or systemic inflammation (80). In another CNS study, Bae et al demonstrated that bone marrow-derived MSC/Purkinje neuron fusion-like events develop into electrically active neurons with functional synaptic formation in the cerebellum of mice with neurodegeneration. Thus, MSCs may be able to integrate into the CNS and contribute to the essential properties of mature neurons (83).

Alvarez-Buylla et al used a simple method based on Cre/lox recombination to detect cell fusion events, demonstrated that bone-marrow-derived cells (BMDCs) fuse spontaneously with neural progenitors in vitro. Furthermore, bone marrow transplantation demonstrates that BMDCs fuse in vivo with hepatocytes in liver, Purkinje neurons in the brain and cardiac muscle in the heart, resulting in the formation of multinucleated cells, suggesting that genetic material derived from BMDCs contribute through cell fusion to the survival and function of these cells (84).

Adnan and colleagues have show that BMDCs can fuse with a long-lived progenitor or intestinal stem cell population of gamma-irradiated damaged intestinal epithelium and can also fuse with tumor epithelium. Fusion of BMDCs with progenitors or stem cells may play an important role in the regeneration of damaged tissue, and the observation that BMDCs can fuse with tumor epithelium is an important finding also, since the study of this event will enhance the understanding of the biology of tumorigenesis and may provide a novel strategy for the development of anticancer therapies (85).

Other clear beneficial effects of heterotypic cell fusion of BMDCs with other cells types have been demonstrated in a mouse model of a lethal liver disease in which the enzyme fumarylacetoacetate hydrolase is absent, and a large numbers of wild-type BMDCs fused with mutant liver cells corrected the metabolic deficiency and ameliorated the disease phenotype (86).

These studies demonstrate that stem cells are able to fuse with cells of different tissues. However, additional studies in animal models will be required to determine whether this fusion can be used in reparative cell therapy.

\subsection{Paracrine factors}

Although there are many ways through which stem cells may ameliorate injury, the main mechanism is considered is through paracrine and endocrine functions. Today, a wide range of cytokines and factors are known to be involved in the beneficial interaction between MSC and other cells.

\subsubsection{Immunomodulation}

Among all theories regarding the paracrine action for MSCs, by far the most explored and discussed by research is immunomodulation. Considering the inflammatory nature of most injuries, studies have indicated that the predominant role of MSCs in resolving tissue 
damage relies on toning down inflammation in specific sites of injury. While there are many factors suggested by literature, the main and most frequently pointed out factors and regulated immune cells are discussed ahead.

Monocytes/Macrophages

Since macrophages are one of the main cells responsible for cytokine production in injury sites, these cells are main focus points when immunomodulation is considered. Recent studies have indicated an important role in mesenchymal stem cell monocyte and macrophage immunomodulation. Maggini et al. amongst others have demonstrated that MSCs inhibit macrophage pro-inflammatory cytokine production, i.e. TNF-a, IL-6 and IFN-g (87-89). MSC also stimulate anti-inflammatory cytokine, IL-10 and IL-12p40 production (87, 88). This way, immune cell activation and the local inflammatory process is contained, reducing tissue damage. MSC also enhance apoptotic cell phagocytosis which is important in clearing injury sites. In addition, these cells inhibit monocyte derived dendritic cell differentiation (90). These effects seem to be due mainly to MSC-derived PGE2 secretion, which has direct effects on macrophage activation.

Dendritic Cells

Dendritic cells (DCs) have essential roles in antigen presentation and lymphocyte profile modulation. MSC are capable of inhibiting DC maturation through cell to cell contact and PDGE2 and IL-6 production, as seen through downregulated expression of CD1a, IL-12p70, MHC class II molecules, CD80 and CD86 $(91,92)$. As T cells depend importantly on antigen presenting cells to become activated, dendritc cell modulation is considered a possible mechanism for T lymphocyte tolerance induction. In addition, MSC treatment also impacts DC migration, as seen in reduced CCR7 expression and reduced migration in response to CCL19 (92). Also, mature type 1 DCs decrease TNF-a production and type 2 DCs increase IL-10 expression which may also induce Th2 profile lymphocytes (93).

T Lymphocytes

Research has shown that $\mathrm{T}$ lymphocyte modulation has an important role in the therapeutic character of MSC. For starters, in a disease setting, a considerable percentage of exogenous MSCs tend to accumulate in the spleen and lymph nodes, in particular around immune cells such as DCs, T and B lymphocytes, suggesting cell-specific interaction (94). MSCs are not considered to display important allogenic properties, being immune-privileged, due to low HLA -DR and costimulatory molecule expression and its basic immunomodulatory properties, although a full consensus does not exist towards the degree in which this happens $(95,96)$. In vitro, MSC inhibit phytohemagglutinin mitogen-induced and mixed lymphocyte reaction allo-antigen driven $\mathrm{T}$ cell proliferation (97-99). This is done by both cell-to-cell contact and humoral factors in specific, secreting IDO and Galectin-1. These stem cells also decrease TNF-a and IFN-g T cell production and raise IL-10 secretion, possibly mediated by IDO, PGE2 and B7-H amongst other molecules (100-102). MSCs also induce Th2 type lymphocyte and T regulatory cell differentiation through, HLA-G5 and other molecules (103-105).

B lymphocytes

Although many works have associated MSC and T lymphocyte regulation, few have indicated a direct role in B lymphocyte function, and many published studies are 
controversial. Yanfei et al have shown that B lymphocytes have decreased proliferation and antibody production when cultivated with MSC regulated allogenic DCs (106). In addition, other studies suggest that MSC directly inhibit B lymphocyte plasma cell differentiation through humoral factors $(107,108)$. On the other hand, other studies indicate that mesenchymal stem cells induce B-cell proliferation and differentiation into plasmocytes, when stimulated with a Toll-like receptor 9 agonist (109). These different results are probably due to the different stimuli used and its detailed effect on B cell outcome is still to be discovered.

\section{NK / iNKT Cells}

Little information is still known on MSC-mediated NK / invariant natural killer T Cells (iNKT) in comparison to other cell types. Studies demonstrate that MSCs inhibit NK and iNKT cell activation and IFN-g production by secretion of mediators as HLA-G5 and PGE2 respectively $(110,111)$. It is also important to mention that NK cells induce MSC lysis, probably due to low HLA class I molecule expression (112, 113). Also, important consideration needs to be given to MSC effects on the immune system in regards to tumor surveillance, due to NK cell inhibition (114).

\subsubsection{Angiogenic factors}

Angiogenic support provided by MSC can be considered one more supportive effect, since the re-establishment of blood supply is fundamental for recovery of damaged tissues. The pro-angiogenic effect of MSC have been demonstrated in several studies in vitro and in vivo (115-118).

It is known that MSCs express and secrete Stromal cell-derived factors 1 (SDF-1), vascular endothelial growth factor (VEGF), and other cytokines important for angiogenesis (Basic Fibroblast Growth Factor (bFGF); Matrix metalloproteinases (MMPs). VEGF has been identified as a key component in the development of blood vessels, but VEGF alone may be insufficient to achieve functional and mature development of the vasculature. VEGFinduced vessels are often leaky and do not connect appropriately to the existing vasculature $(119,120)$. SDF-1 activity is essential for endothelial cell survival, vascular branching and pericyte recruitment (121). Interestingly, SDF-1a is not only a mobilization signal capable of recruiting CXCR4- positive progenitor cells into hypoxic tissues but also a retention signal for angiocompentent bone marrow-derived stem cells. It also recruits pericytes and smooth muscle cells to stabilize and mature newly formed blood vessels $(122,123)$. Thus, SDF-1 has been shown to augment neovascularization by the acceleration of endothelial progenitor cell (EPC) recruitment into ischemic foci $(122,124)$. In addition, VEGF is one of the powerful angiogenic cytokines that can also mobilize EPCs from bone marrow and inhibit EPC apoptosis (125). In the mouse ischemic hind limb model, VEGF-A-mediated angiogenesis partly depends on the activation of the SDF-1-CXCR4 pathway (124). Taken together, the chemokine SDF-1 likely plays a pivotal role in ASC-mediated angiogenesis (126).

Interestingly, studies have demonstrated that mesenchymal stem cells have the same angiogenesis property. Shintani et al demonstrated that implantation of autologous bone marrow mononuclear cells into ischemic skeletal muscles successfully augmented angiogenesis and collateral vessel formation in both animal studies and human trials (127129). The same group found that implantation of ASC significantly augmented angiogenesis in a mouse model of hind limb ischemia, by release chemokines such as SDF-1 (126). Kim et al. demonstrated in a preliminary clinical trial that implantation of 
human cord blood-derived mesenchymal stem cells enhanced angiogenesis and collateral vessel formation in human cases with Buerger's disease (130). Kamihata and colleagues have reported that bone marrow mononuclear cells that survived engrafting can synthesize angiogenic factors such as VEGF, bFGF, and angiopoietin-1 to induce angiogenesis in the ischemic myocardium (128).

In summary, engrafting MSC in clinical therapy has a beneficial effect, which may be attributable to paracrine action. MSC secrete a number of angiogenic factors and stem cell homing factor that are able to re-establishment of blood supply, being this fundamental for the recovery of damaged tissues.

\subsubsection{Anti-apoptotic factors}

An important role in MSC-mediated protection is its inhibition of tissue apoptosis and augmentation of tissue turnover. Studies show that MSC are capable of inhibiting apoptosis in kidney, liver and brain injuries (30,131-133). Recent evidence shows that this is done through increasing prosurvival factors as Akt expression in injured cells (55), BDNF and growth factors as IGF, VEGF and HGF expression which inhibit apoptosis and stimulate cell proliferation $(134,135)$. Together, this dynamic permits high cell turn-over, renewing damaged cells and decreasing excessive cell death, thus restoring normal tissue physiology.

\subsubsection{Anti-oxidative factors}

It is well known that MSC mediate tissue repair through paracrine mechanisms. Besides mediating directly in the inflammatory process, some studies have suggested that MSC also posses anti-oxidative characteristics. MSC have been observed to produce many antioxidative mediators such as IGF, PDGF, superoxide dismutase (SOD), HGF and IL-6 (136139). MSC-conditioned media has also been seen to contain these anti-oxidative factors including G-CSF, GM-CSF and IL-12, as reviewed by Kim et al (140). In addition, evidence has supported that MSC and its conditioned media respectively decrease oxidative damage in culture when fibroblast cells are exposed to oxidative damage-inducing environments such as UVB (141) or tert-butyl hydroperoxide (tbOOH) (142).

In addition, research indicates that MSC posses not only considerable ability to support oxidative stress by producing anti-oxidative mediators, but may actually be stimulated by hipoxia-induced ROS (reactive oxigen species). During oxidative stress, MSC seem to have increased proliferation and migration mediated by the Akt and Erk pathways and plateletderived growth factor receptor- $\beta$ (PDGFR- $\beta$ ) phosphorylation $(143,144)$. This however is still controversial. Other studies indicate that oxidative stress correlates with MSC senescence (145, 146). These different results may be consequent to different ROS inductors, and consequently, different levels of ROS production and enviromental contributing factors envolved.

\subsection{Microvesicles and miRNA}

The paracrine action of MSC is now well accepted. In this sense, administration of conditioned medium of stem cell in an animal model of kidney injury has demonstrated to improve in clinical parameter outcomes correlated with decreased apoptosis and ameliorated histological parameters. Despite the bioactive molecules secreted by MSC, Bruno et al have showed that inside the conditioned medium also there are some microvesicules.

These microvesicles (MVs) are circular membranes fragments that shed from the cell surface membrane carrying protein and lipids from the membranes of the cells from which they 
originate. Besides this, MVs may also carry mRNA and microRNA stablishing a communication between one cell and another (147). Shedding of microvesicles is a physiologic process, however some stress conditions lead to an increase in the number of MV shed (148).

Camussi's group has described that mesenchymal stem cells are able to shed microvesicles, and moreover, these MVs carry mRNA and microRNA leading to amelioration of acute and chronic experimental models of renal injury, accelerating regeneration of hepatectomized rats and activating endothelial cells $(30,149-151)$.

\section{Long term aspects of MSC therapy: cancer, immunosuppression or maldifferentiation?}

The majority of pre-clinical and clinical studies, which are going on, are incipient. They analyzed the results of treatment in few months or years, not allowing long-term analysis. In these early results, MSC therapy has not shown adverse effects, being designated safe by FDA (152). Thus it is difficult to tell if MSC treatment per se may lead to cancer. Nevertheless, several studies have showed that MSC after infusion do not engraft in any tissue, emphasizing the paracrine mechanism of action (152). However, if the treatment is continuous or the MSC administration is repeated, MSC can be found in the injured tissue (32). When MSC is engrafted or even when there is an in situ administration, MSC may maldifferentiate. In a model of glomerulonephritis, MSC maldifferentiate to adipose cells in the kidney (35). In situ administration of human autologous stem cell therapy in a patient with lupus nephritis has induced angiomyeloproliferative lesions at the sites of injection and hematuria (153).

All bioactive molecules secreted by MSC are prone to stimulate cancer cells to proliferate and migrate. Some works correlate MSC to suppression of tumor growth, others to supporting it. Several questions may be related to its discrepancy: animal host, timing of injection of MSC, differences in tumor models, etc (154). In addition, MSC may differentiate to tumor associated fibroblast (TAF), cells that support tumor growth (155). Thus, MSC therapy should exclude patients with cancer family history.

Also, the immunossupression level of MSC therapy cannot be controlled. Once MSC are injected endovenously, immunossupression is achieved. MSC therapy may compromise the host's defense against infections agents (156).

\section{Final considerations}

Many advances have been made in the field of mesenchymal stem cells. Nowadays much is known about what the MSC is and how is the mechanism of action. Currently, existing therapies administered exogenous MSC to treat several diseases. Perhaps, a deeper knowledge on endogenous stem cells may bring advances on cell therapy. To activate endogenous stem cells, via stimulation of the niche is an interesting therapeutic perspective. In addition, try to understand what happens to this endogenous stem cell in pathological state is one of the highlights to be discovered.

In the conventional therapy - administration of exogenous MSC - many issues are yet to be solved: amount of injected MSC, the best route of administration, the culture conditions which are not standardized with the use of materials of animal origin, which is the best source for these cells, etc. In conclusion, the field of MSC is very fruitful and still requires to be further studied. 


\section{References}

[1] Gurtner GC, Callaghan MJ, Longaker MT. Progress and potential for regenerative medicine. Annu Rev Med. 2007;58:299-312.

[2] Friedenstein AJ, Chailakhjan RK, Lalykina KS. The development of fibroblast colonies in monolayer cultures of guinea-pig bone marrow and spleen cells. Cell Tissue Kinet. 1970 Oct;3(4):393-403.

[3] Friedenstein AJ, Latzinik NW, Grosheva AG, Gorskaya UF. Marrow microenvironment transfer by heterotopic transplantation of freshly isolated and cultured cells in porous sponges. Exp Hematol. 1982 Feb;10(2):217-27.

[4] Luria EA, Owen ME, Friedenstein AJ, Morris JF, Kuznetsow SA. Bone formation in organ cultures of bone marrow. Cell Tissue Res. 1987 May;248(2):449-54.

[5] Caplan AI. Mesenchymal stem cells. J Orthop Res. 1991 Sep;9(5):641-50.

[6] Caplan AI. The mesengenic process. Clin Plast Surg. 1994 Jul;21(3):429-35.

[7] Pittenger MF, Mackay AM, Beck SC, Jaiswal RK, Douglas R, Mosca JD, et al. Multilineage potential of adult human mesenchymal stem cells. Science. 1999 Apr 2;284(5411):143-7.

[8] Zuk PA, Zhu M, Ashjian P, De Ugarte DA, Huang JI, Mizuno H, et al. Human adipose tissue is a source of multipotent stem cells. Mol Biol Cell. 2002 Dec;13(12):4279-95.

[9] Gabbay JS, Heller JB, Mitchell SA, Zuk PA, Spoon DB, Wasson KL, et al. Osteogenic potentiation of human adipose-derived stem cells in a 3-dimensional matrix. Ann Plast Surg. 2006 Jul;57(1):89-93.

[10] Polisetty N, Fatima A, Madhira SL, Sangwan VS, Vemuganti GK. Mesenchymal cells from limbal stroma of human eye. Mol Vis. 2008;14:431-42.

[11] Diaz-Prado S, Muinos-Lopez E, Hermida-Gomez T, Rendal-Vazquez ME, FuentesBoquete I, de Toro FJ, et al. Multilineage differentiation potential of cells isolated from the human amniotic membrane. J Cell Biochem. Nov 1;111(4):846-57.

[12] Perin L, Sedrakyan S, Da Sacco S, De Filippo R. Characterization of human amniotic fluid stem cells and their pluripotential capability. Methods Cell Biol. 2008;86:85-99.

[13] Bussolati B, Bruno S, Grange C, Buttiglieri S, Deregibus MC, Cantino D, et al. Isolation of renal progenitor cells from adult human kidney. Am J Pathol. 2005 Feb;166(2):545-55.

[14] Horwitz EM, Le Blanc K, Dominici M, Mueller I, Slaper-Cortenbach I, Marini FC, et al. Clarification of the nomenclature for MSC: The International Society for Cellular Therapy position statement. Cytotherapy. 2005;7(5):393-5.

[15] Dominici M, Le Blanc K, Mueller I, Slaper-Cortenbach I, Marini F, Krause D, et al. Minimal criteria for defining multipotent mesenchymal stromal cells. The International Society for Cellular Therapy position statement. Cytotherapy. 2006;8(4):315-7.

[16] Caplan AI. What's in a name? Tissue Eng Part A. Aug;16(8):2415-7.

[17] Peroni D, Scambi I, Pasini A, Lisi V, Bifari F, Krampera M, et al. Stem molecular signature of adipose-derived stromal cells. Exp Cell Res. 2008 Feb 1;314(3):603-15.

[18] Panepucci RA, Siufi JL, Silva WA, Jr., Proto-Siquiera R, Neder L, Orellana M, et al. Comparison of gene expression of umbilical cord vein and bone marrow-derived mesenchymal stem cells. Stem Cells. 2004;22(7):1263-78.

[19] Park HW, Shin JS, Kim CW. Proteome of mesenchymal stem cells. Proteomics. 2007 Aug;7(16):2881-94.

[20] Ferraro F, Celso CL, Scadden D. Adult stem cels and their niches. Adv Exp Med Biol.695:155-68. 
[21] Voog J, Jones DL. Stem cells and the niche: a dynamic duo. Cell Stem Cell. Feb $5 ; 6(2): 103-15$.

[22] Walker MR, Patel KK, Stappenbeck TS. The stem cell niche. J Pathol. 2009 Jan;217(2):169-80.

[23] Li L, Neaves WB. Normal stem cells and cancer stem cells: the niche matters. Cancer Res. 2006 May 1;66(9):4553-7.

[24] Inomata K, Aoto T, Binh NT, Okamoto N, Tanimura S, Wakayama T, et al. Genotoxic stress abrogates renewal of melanocyte stem cells by triggering their differentiation. Cell. 2009 Jun 12;137(6):1088-99.

[25] Mimeault M, Batra SK. Aging of tissue-resident adult stem/progenitor cells and their pathological consequences. Panminerva Med. 2009 Jun;51(2):57-79.

[26] Feng J, Mantesso A, Sharpe PT. Perivascular cells as mesenchymal stem cells. Expert Opin Biol Ther. Oct;10(10):1441-51.

[27] da Silva Meirelles L, Caplan AI, Nardi NB. In search of the in vivo identity of mesenchymal stem cells. Stem Cells. 2008 Sep;26(9):2287-99.

[28] da Silva Meirelles L, Sand TT, Harman RJ, Lennon DP, Caplan AI. MSC frequency correlates with blood vessel density in equine adipose tissue. Tissue Eng Part A. 2009 Feb;15(2):221-9.

[29] Semedo P, Wang PM, Andreucci TH, Cenedeze MA, Teixeira VP, Reis MA, et al. Mesenchymal stem cells ameliorate tissue damages triggered by renal ischemia and reperfusion injury. Transplant Proc. 2007 Mar;39(2):421-3.

[30] Bruno S, Grange C, Deregibus MC, Calogero RA, Saviozzi S, Collino F, et al. Mesenchymal stem cell-derived microvesicles protect against acute tubular injury. J Am Soc Nephrol. 2009 May;20(5):1053-67.

[31] Togel F, Weiss K, Yang Y, Hu Z, Zhang P, Westenfelder C. Vasculotropic, paracrine actions of infused mesenchymal stem cells are important to the recovery from acute kidney injury. Am J Physiol Renal Physiol. 2007 May;292(5):F1626-35.

[32] Semedo P, Correa-Costa M, Antonio Cenedeze M, Maria Avancini Costa Malheiros D, Antonia dos Reis M, Shimizu MH, et al. Mesenchymal stem cells attenuate renal fibrosis through immune modulation and remodeling properties in a rat remnant kidney model. Stem Cells. 2009 Dec;27(12):3063-73.

[33] Choi S, Park M, Kim J, Hwang S, Park S, Lee Y. The role of mesenchymal stem cells in the functional improvement of chronic renal failure. Stem Cells Dev. 2009 Apr;18(3):521-9.

[34] Asanuma H, Vanderbrink BA, Campbell MT, Hile KL, Zhang H, Meldrum DR, et al. Arterially Delivered Mesenchymal Stem Cells Prevent Obstruction-Induced Renal Fibrosis. J Surg Res. Jul 8.

[35] Kunter U, Rong S, Boor P, Eitner F, Muller-Newen G, Djuric Z, et al. Mesenchymal stem cells prevent progressive experimental renal failure but maldifferentiate into glomerular adipocytes. J Am Soc Nephrol. 2007 Jun;18(6):1754-64.

[36] Shake JG, Gruber PJ, Baumgartner WA, Senechal G, Meyers J, Redmond JM, et al. Mesenchymal stem cell implantation in a swine myocardial infarct model: engraftment and functional effects. Ann Thorac Surg. 2002 Jun;73(6):1919-25; discussion 26.

[37] Samdani AF, Paul C, Betz RR, Fischer I, Neuhuber B. Transplantation of human marrow stromal cells and mono-nuclear bone marrow cells into the injured spinal cord: a comparative study. Spine (Phila Pa 1976). 2009 Nov 15;34(24):2605-12. 
[38] Danielyan L, Schafer R, von Ameln-Mayerhofer A, Bernhard F, Verleysdonk S, Buadze $\mathrm{M}$, et al. Therapeutic efficacy of intranasally delivered mesenchymal stem cells in a rat model of Parkinson disease. Rejuvenation Res. Feb;14(1):3-16.

[39] Abdel Aziz MT, Atta HM, Mahfouz S, Fouad HH, Roshdy NK, Ahmed HH, et al. Therapeutic potential of bone marrow-derived mesenchymal stem cells on experimental liver fibrosis. Clin Biochem. 2007 Aug;40(12):893-9.

[40] Xu J, Qu J, Cao L, Sai Y, Chen C, He L, et al. Mesenchymal stem cell-based angiopoietin1 gene therapy for acute lung injury induced by lipopolysaccharide in mice. J Pathol. 2008 Mar;214(4):472-81.

[41] Ortiz LA, Gambelli F, McBride C, Gaupp D, Baddoo M, Kaminski N, et al. Mesenchymal stem cell engraftment in lung is enhanced in response to bleomycin exposure and ameliorates its fibrotic effects. Proc Natl Acad Sci U S A. 2003 Jul 8;100(14):8407-11.

[42] Madec AM, Mallone R, Afonso G, Abou Mrad E, Mesnier A, Eljaafari A, et al. Mesenchymal stem cells protect NOD mice from diabetes by inducing regulatory $\mathrm{T}$ cells. Diabetologia. 2009 Jul;52(7):1391-9.

[43] Le Blanc K, Frassoni F, Ball L, Locatelli F, Roelofs H, Lewis I, et al. Mesenchymal stem cells for treatment of steroid-resistant, severe, acute graft-versus-host disease: a phase II study. Lancet. 2008 May 10;371(9624):1579-86.

[44] Tateishi-Yuyama E, Matsubara H, Murohara T, Ikeda U, Shintani S, Masaki H, et al. Therapeutic angiogenesis for patients with limb ischaemia by autologous transplantation of bone-marrow cells: a pilot study and a randomised controlled trial. Lancet. 2002 Aug 10;360(9331):427-35.

[45] Togel FE, Westenfelder C. Mesenchymal stem cells: a new therapeutic tool for AKI. Nat Rev Nephrol. Mar;6(3):179-83.

[46] Matthay MA. Treatment of acute lung injury: clinical and experimental studies. Proc Am Thorac Soc. 2008 Apr 15;5(3):297-9.

[47] Yang Z, Zhang F, Ma W, Chen B, Zhou F, Xu Z, et al. A novel approach to transplanting bone marrow stem cells to repair human myocardial infarction: delivery via a noninfarct-relative artery. Cardiovasc Ther. Dec;28(6):380-5.

[48] Banas A, Yamamoto Y, Teratani T, Ochiya T. Stem cell plasticity: learning from hepatogenic differentiation strategies. Dev Dyn. 2007 Dec;236(12):3228-41.

[49] Loeffler M, Bratke T, Paulus U, Li YQ, Potten CS. Clonality and life cycles of intestinal crypts explained by a state dependent stochastic model of epithelial stem cell organization. J Theor Biol. 1997 May 7;186(1):41-54.

[50] Loeffler M, Roeder I. Tissue stem cells: definition, plasticity, heterogeneity, selforganization and models--a conceptual approach. Cells Tissues Organs. 2002;171(1):8-26.

[51] Kotton DN, Ma BY, Cardoso WV, Sanderson EA, Summer RS, Williams MC, et al. Bone marrow-derived cells as progenitors of lung alveolar epithelium. Development. 2001 Dec;128(24):5181-8.

[52] Rojas M, Xu J, Woods CR, Mora AL, Spears W, Roman J, et al. Bone marrow-derived mesenchymal stem cells in repair of the injured lung. Am J Respir Cell Mol Biol. 2005 Aug;33(2):145-52.

[53] Arnhold S, Absenger Y, Klein H, Addicks K, Schraermeyer U. Transplantation of bone marrow-derived mesenchymal stem cells rescue photoreceptor cells in the dystrophic retina of the rhodopsin knockout mouse. Graefes Arch Clin Exp Ophthalmol. 2007 Mar;245(3):414-22. 
[54] Nakagawa H, Akita S, Fukui M, Fujii T, Akino K. Human mesenchymal stem cells successfully improve skin-substitute wound healing. Br J Dermatol. 2005 Jul;153(1):29-36.

[55] Morigi M, Imberti B, Zoja C, Corna D, Tomasoni S, Abbate M, et al. Mesenchymal stem cells are renotropic, helping to repair the kidney and improve function in acute renal failure. J Am Soc Nephrol. 2004 Jul;15(7):1794-804.

[56] Scintu F, Reali C, Pillai R, Badiali M, Sanna MA, Argiolu F, et al. Differentiation of human bone marrow stem cells into cells with a neural phenotype: diverse effects of two specific treatments. BMC Neurosci. 2006;7:14.

[57] Alhadlaq A, Elisseeff JH, Hong L, Williams CG, Caplan AI, Sharma B, et al. Adult stem cell driven genesis of human-shaped articular condyle. Ann Biomed Eng. 2004 Jul;32(7):911-23.

[58] Jorgensen NR, Henriksen Z, Sorensen OH, Civitelli R. Dexamethasone, BMP-2, and 1,25-dihydroxyvitamin $\mathrm{D}$ enhance a more differentiated osteoblast phenotype: validation of an in vitro model for human bone marrow-derived primary osteoblasts. Steroids. 2004 Apr;69(4):219-26.

[59] Sun S, Liu Y, Lipsky S, Cho M. Physical manipulation of calcium oscillations facilitates osteodifferentiation of human mesenchymal stem cells. FASEB J. 2007 May;21(7):1472-80.

[60] McBeath R, Pirone DM, Nelson CM, Bhadriraju K, Chen CS. Cell shape, cytoskeletal tension, and RhoA regulate stem cell lineage commitment. Dev Cell. 2004 Apr;6(4):483-95.

[61] Engler AJ, Sen S, Sweeney HL, Discher DE. Matrix elasticity directs stem cell lineage specification. Cell. 2006 Aug 25;126(4):677-89.

[62] Geiger B, Bershadsky A, Pankov R, Yamada KM. Transmembrane crosstalk between the extracellular matrix--cytoskeleton crosstalk. Nat Rev Mol Cell Biol. 2001 Nov;2(11):793-805.

[63] Altman GH, Horan RL, Martin I, Farhadi J, Stark PR, Volloch V, et al. Cell differentiation by mechanical stress. FASEB J. 2002 Feb;16(2):270-2.

[64] Yoshikawa T, Peel SA, Gladstone JR, Davies JE. Biochemical analysis of the response in rat bone marrow cell cultures to mechanical stimulation. Biomed Mater Eng. 1997;7(6):369-77.

[65] Sumanasinghe RD, Bernacki SH, Loboa EG. Osteogenic differentiation of human mesenchymal stem cells in collagen matrices: effect of uniaxial cyclic tensile strain on bone morphogenetic protein (BMP-2) mRNA expression. Tissue Eng. 2006 Dec;12(12):3459-65.

[66] Ward DF, Jr., Salasznyk RM, Klees RF, Backiel J, Agius P, Bennett K, et al. Mechanical strain enhances extracellular matrix-induced gene focusing and promotes osteogenic differentiation of human mesenchymal stem cells through an extracellular-related kinase-dependent pathway. Stem Cells Dev. 2007 Jun;16(3):467-80.

[67] Wu CC, Chao YC, Chen CN, Chien S, Chen YC, Chien CC, et al. Synergism of biochemical and mechanical stimuli in the differentiation of human placentaderived multipotent cells into endothelial cells. J Biomech. 2008;41(4):813-21.

[68] Delorme B, Ringe J, Pontikoglou C, Gaillard J, Langonne A, Sensebe L, et al. Specific lineage-priming of bone marrow mesenchymal stem cells provides the molecular framework for their plasticity. Stem Cells. 2009 May;27(5):1142-51. 
[69] Montzka K, Lassonczyk N, Tschoke B, Neuss S, Fuhrmann T, Franzen R, et al. Neural differentiation potential of human bone marrow-derived mesenchymal stromal cells: misleading marker gene expression. BMC Neurosci. 2009;10:16.

[70] Dezawa M, Ishikawa H, Itokazu Y, Yoshihara T, Hoshino M, Takeda S, et al. Bone marrow stromal cells generate muscle cells and repair muscle degeneration. Science. 2005 Jul 8;309(5732):314-7.

[71] Huang S. Reprogramming cell fates: reconciling rarity with robustness. Bioessays. 2009 May;31(5):546-60.

[72] Kotobuki N, Hirose M, Takakura Y, Ohgushi H. Cultured autologous human cells for hard tissue regeneration: preparation and characterization of mesenchymal stem cells from bone marrow. Artif Organs. 2004 Jan;28(1):33-9.

[73] Fouillard L, Chapel A, Bories D, Bouchet S, Costa JM, Rouard H, et al. Infusion of allogeneic-related HLA mismatched mesenchymal stem cells for the treatment of incomplete engraftment following autologous haematopoietic stem cell transplantation. Leukemia. 2007 Mar;21(3):568-70.

[74] Toma C, Pittenger MF, Cahill KS, Byrne BJ, Kessler PD. Human mesenchymal stem cells differentiate to a cardiomyocyte phenotype in the adult murine heart. Circulation. 2002 Jan 1;105(1):93-8.

[75] Wu Y, Chen L, Scott PG, Tredget EE. Mesenchymal stem cells enhance wound healing through differentiation and angiogenesis. Stem Cells. 2007 Oct;25(10):2648-59.

[76] Sasaki M, Abe R, Fujita Y, Ando S, Inokuma D, Shimizu H. Mesenchymal stem cells are recruited into wounded skin and contribute to wound repair by transdifferentiation into multiple skin cell type. J Immunol. 2008 Feb 15;180(4):25817.

[77] Anghileri E, Marconi S, Pignatelli A, Cifelli P, Galie M, Sbarbati A, et al. Neuronal differentiation potential of human adipose-derived mesenchymal stem cells. Stem Cells Dev. 2008 Oct;17(5):909-16.

[78] Munoz-Elias G, Woodbury D, Black IB. Marrow stromal cells, mitosis, and neuronal differentiation: stem cell and precursor functions. Stem Cells. 2003;21(4):437-48.

[79] Singec I, Snyder EY. Inflammation as a matchmaker: revisiting cell fusion. Nat Cell Biol. 2008 May;10(5):503-5.

[80] Johansson CB, Youssef S, Koleckar K, Holbrook C, Doyonnas R, Corbel SY, et al. Extensive fusion of haematopoietic cells with Purkinje neurons in response to chronic inflammation. Nat Cell Biol. 2008 May;10(5):575-83.

[81] Nygren JM, Liuba K, Breitbach M, Stott S, Thoren L, Roell W, et al. Myeloid and lymphoid contribution to non-haematopoietic lineages through irradiation-induced heterotypic cell fusion. Nat Cell Biol. 2008 May;10(5):584-92.

[82] Kemp K, Gordon D, Wraith DC, Mallam E, Hartfield E, Uney J, et al. Fusion between human mesenchymal stem cells and rodent cerebellar Purkinje cells. Neuropathol Appl Neurobiol. Feb;37(2):166-78.

[83] Bae JS, Han HS, Youn DH, Carter JE, Modo M, Schuchman EH, et al. Bone marrowderived mesenchymal stem cells promote neuronal networks with functional synaptic transmission after transplantation into mice with neurodegeneration. Stem Cells. 2007 May;25(5):1307-16.

[84] Alvarez-Dolado M, Pardal R, Garcia-Verdugo JM, Fike JR, Lee HO, Pfeffer K, et al. Fusion of bone-marrow-derived cells with Purkinje neurons, cardiomyocytes and hepatocytes. Nature. 2003 Oct 30;425(6961):968-73. 
[85] Rizvi AZ, Swain JR, Davies PS, Bailey AS, Decker AD, Willenbring $H$, et al. Bone marrow-derived cells fuse with normal and transformed intestinal stem cells. Proc Natl Acad Sci U S A. 2006 Apr 18;103(16):6321-5.

[86] Wang X, Willenbring H, Akkari Y, Torimaru Y, Foster M, Al-Dhalimy M, et al. Cell fusion is the principal source of bone-marrow-derived hepatocytes. Nature. 2003 Apr 24;422(6934):897-901.

[87] Maggini J, Mirkin G, Bognanni I, Holmberg J, Piazzon IM, Nepomnaschy I, et al. Mouse bone marrow-derived mesenchymal stromal cells turn activated macrophages into a regulatory-like profile. PLoS One.5(2):e9252.

[88] Nemeth K, Leelahavanichkul A, Yuen PS, Mayer B, Parmelee A, Doi K, et al. Bone marrow stromal cells attenuate sepsis via prostaglandin E(2)-dependent reprogramming of host macrophages to increase their interleukin-10 production. Nat Med. 2009 Jan;15(1):42-9.

[89] Zhang QZ, Su WR, Shi SH, Wilder-Smith P, Xiang AP, Wong A, et al. Human gingivaderived mesenchymal stem cells elicit polarization of $\mathrm{m} 2$ macrophages and enhance cutaneous wound healing. Stem Cells. Oct;28(10):1856-68.

[90] Kronsteiner B, Peterbauer-Scherb A, Grillari-Voglauer R, Redl H, Gabriel C, van Griensven $\mathrm{M}$, et al. Human mesenchymal stem cells and renal tubular epithelial cells differentially influence monocyte-derived dendritic cell differentiation and maturation. Cell Immunol.267(1):30-8.

[91] Djouad F, Charbonnier LM, Bouffi C, Louis-Plence P, Bony C, Apparailly F, et al. Mesenchymal stem cells inhibit the differentiation of dendritic cells through an interleukin-6-dependent mechanism. Stem Cells. 2007 Aug;25(8):2025-32.

[92] English K, Barry FP, Mahon BP. Murine mesenchymal stem cells suppress dendritic cell migration, maturation and antigen presentation. Immunol Lett. 2008 Jan 15;115(1):50-8.

[93] Aggarwal S, Pittenger MF. Human mesenchymal stem cells modulate allogeneic immune cell responses. Blood. 2005 Feb 15;105(4):1815-22.

[94] Lim JH, Kim JS, Yoon IH, Shin JS, Nam HY, Yang SH, et al. Immunomodulation of delayed-type hypersensitivity responses by mesenchymal stem cells is associated with bystander $\mathrm{T}$ cell apoptosis in the draining lymph node. J Immunol. Oct 1;185(7):4022-9.

[95] Fang L, Lange C, Engel M, Zander AR, Fehse B. Sensitive balance of suppressing and activating effects of mesenchymal stem cells on T-cell proliferation. Transplantation. 2006 Nov 27;82(10):1370-3.

[96] Deuse T, Stubbendorff M, Tang-Quan K, Phillips N, Kay MA, Eiermann T, et al. Immunogenicity and immunomodulatory properties of umbilical cord lining mesenchymal stem cells. Cell Transplant. Nov 5.

[97] Prasanna SJ, Gopalakrishnan D, Shankar SR, Vasandan AB. Pro-inflammatory cytokines, IFNgamma and TNFalpha, influence immune properties of human bone marrow and Wharton jelly mesenchymal stem cells differentially. PLoS One.5(2):e9016.

[98] Gieseke F, Bohringer J, Bussolari R, Dominici M, Handgretinger R, Muller I. Human multipotent mesenchymal stromal cells use galectin-1 to inhibit immune effector cells. Blood. Nov 11;116(19):3770-9.

[99] Meisel R, Zibert A, Laryea M, Gobel U, Daubener W, Dilloo D. Human bone marrow stromal cells inhibit allogeneic T-cell responses by indoleamine 2,3-dioxygenasemediated tryptophan degradation. Blood. 2004 Jun 15;103(12):4619-21. 
[100] Yoo KH, Jang IK, Lee MW, Kim HE, Yang MS, Eom Y, et al. Comparison of immunomodulatory properties of mesenchymal stem cells derived from adult human tissues. Cell Immunol. 2009;259(2):150-6.

[101] Tipnis S, Viswanathan C, Majumdar AS. Immunosuppressive properties of human umbilical cord-derived mesenchymal stem cells: role of B7-H1 and IDO. Immunol Cell Biol. Nov-Dec;88(8):795-806.

[102] Najar M, Raicevic G, Boufker HI, Fayyad Kazan H, De Bruyn C, Meuleman N, et al. Mesenchymal stromal cells use PGE2 to modulate activation and proliferation of lymphocyte subsets: Combined comparison of adipose tissue, Wharton's Jelly and bone marrow sources. Cell Immunol.264(2):171-9.

[103] Bouffi C, Bony C, Courties G, Jorgensen C, Noel D. IL-6-dependent PGE2 secretion by mesenchymal stem cells inhibits local inflammation in experimental arthritis. PLoS One.5(12):e14247.

[104] Augello A, Tasso R, Negrini SM, Cancedda R, Pennesi G. Cell therapy using allogeneic bone marrow mesenchymal stem cells prevents tissue damage in collagen-induced arthritis. Arthritis Rheum. 2007 Apr;56(4):1175-86.

[105] Selmani Z, Naji A, Zidi I, Favier B, Gaiffe E, Obert L, et al. Human leukocyte antigenG5 secretion by human mesenchymal stem cells is required to suppress $\mathrm{T}$ lymphocyte and natural killer function and to induce CD4+CD25highFOXP3+ regulatory T cells. Stem Cells. 2008 Jan;26(1):212-22.

[106] Huang Y, Chen P, Zhang CB, Ko GJ, Ruiz M, Fiorina P, et al. Kidney-derived mesenchymal stromal cells modulate dendritic cell function to suppress alloimmune responses and delay allograft rejection. Transplantation. Dec 27;90(12):1307-11.

[107] Corcione A, Benvenuto F, Ferretti E, Giunti D, Cappiello V, Cazzanti F, et al. Human mesenchymal stem cells modulate B-cell functions. Blood. 2006 Jan 1;107(1):367-72.

[108] Asari S, Itakura S, Ferreri K, Liu CP, Kuroda Y, Kandeel F, et al. Mesenchymal stem cells suppress B-cell terminal differentiation. Exp Hematol. 2009 May;37(5):604-15.

[109] Traggiai E, Volpi S, Schena F, Gattorno M, Ferlito F, Moretta L, et al. Bone marrowderived mesenchymal stem cells induce both polyclonal expansion and differentiation of $\mathrm{B}$ cells isolated from healthy donors and systemic lupus erythematosus patients. Stem Cells. 2008 Feb;26(2):562-9.

[110] Patel SA, Meyer JR, Greco SJ, Corcoran KE, Bryan M, Rameshwar P. Mesenchymal stem cells protect breast cancer cells through regulatory $\mathrm{T}$ cells: role of mesenchymal stem cell-derived TGF-beta. J Immunol. May 15;184(10):5885-94.

[111] Prigione I, Benvenuto F, Bocca P, Battistini L, Uccelli A, Pistoia V. Reciprocal interactions between human mesenchymal stem cells and gammadelta $\mathrm{T}$ cells or invariant natural killer T cells. Stem Cells. 2009 Mar;27(3):693-702.

[112] Jewett A, Arasteh A, Tseng HC, Behel A, Arasteh H, Yang W, et al. Strategies to rescue mesenchymal stem cells (MSCs) and dental pulp stem cells (DPSCs) from NK cell mediated cytotoxicity. PLoS One.5(3):e9874.

[113] Spaggiari GM, Capobianco A, Becchetti S, Mingari MC, Moretta L. Mesenchymal stem cell-natural killer cell interactions: evidence that activated NK cells are capable of killing MSCs, whereas MSCs can inhibit IL-2-induced NK-cell proliferation. Blood. 2006 Feb 15;107(4):1484-90.

[114] Li Y, Qu YH, Wu YF, Wang XP, Wei J, Huang WG, et al. Bone marrow mesenchymal stem cells reduce the antitumor activity of cytokine-induced killer/natural killer cells in K562 NOD/SCID mice. Ann Hematol. Jan 15. 
[115] Kinnaird T, Stabile E, Burnett MS, Shou M, Lee CW, Barr S, et al. Local delivery of marrow-derived stromal cells augments collateral perfusion through paracrine mechanisms. Circulation. 2004 Mar 30;109(12):1543-9.

[116] Hung SC, Pochampally RR, Chen SC, Hsu SC, Prockop DJ. Angiogenic effects of human multipotent stromal cell conditioned medium activate the PI3K-Akt pathway in hypoxic endothelial cells to inhibit apoptosis, increase survival, and stimulate angiogenesis. Stem Cells. 2007 Sep;25(9):2363-70.

[117] Sorrell JM, Baber MA, Caplan AI. Influence of adult mesenchymal stem cells on in vitro vascular formation. Tissue Eng Part A. 2009 Jul;15(7):1751-61.

[118] Sanz L, Santos-Valle P, Alonso-Camino V, Salas C, Serrano A, Vicario JL, et al. Longterm in vivo imaging of human angiogenesis: critical role of bone marrow-derived mesenchymal stem cells for the generation of durable blood vessels. Microvasc Res. 2008 Apr;75(3):308-14.

[119] Zentilin L, Tafuro S, Zacchigna S, Arsic N, Pattarini L, Sinigaglia M, et al. Bone marrow mononuclear cells are recruited to the sites of VEGF-induced neovascularization but are not incorporated into the newly formed vessels. Blood. 2006 May 1;107(9):3546-54.

[120] Carmeliet P. VEGF gene therapy: stimulating angiogenesis or angioma-genesis? Nat Med. 2000 Oct;6(10):1102-3.

[121] Nagasawa T, Nakajima T, Tachibana K, Iizasa H, Bleul CC, Yoshie O, et al. Molecular cloning and characterization of a murine pre-B-cell growth-stimulating factor/stromal cell-derived factor 1 receptor, a murine homolog of the human immunodeficiency virus 1 entry coreceptor fusin. Proc Natl Acad Sci U S A. 1996 Dec 10;93(25):14726-9.

[122] Yamaguchi J, Kusano KF, Masuo O, Kawamoto A, Silver M, Murasawa S, et al. Stromal cell-derived factor-1 effects on ex vivo expanded endothelial progenitor cell recruitment for ischemic neovascularization. Circulation. 2003 Mar 11;107(9):1322-8.

[123] Grunewald M, Avraham I, Dor Y, Bachar-Lustig E, Itin A, Jung S, et al. VEGF-induced adult neovascularization: recruitment, retention, and role of accessory cells. Cell. 2006 Jan 13;124(1):175-89.

[124] Hiasa K, Ishibashi M, Ohtani K, Inoue S, Zhao Q, Kitamoto S, et al. Gene transfer of stromal cell-derived factor-1alpha enhances ischemic vasculogenesis and angiogenesis via vascular endothelial growth factor/endothelial nitric oxide synthase-related pathway: next-generation chemokine therapy for therapeutic neovascularization. Circulation. 2004 May 25;109(20):2454-61.

[125] Asahara T, Takahashi T, Masuda H, Kalka C, Chen D, Iwaguro H, et al. VEGF contributes to postnatal neovascularization by mobilizing bone marrow-derived endothelial progenitor cells. EMBO J. 1999 Jul 15;18(14):3964-72.

[126] Kondo K, Shintani S, Shibata R, Murakami H, Murakami R, Imaizumi M, et al. Implantation of adipose-derived regenerative cells enhances ischemia-induced angiogenesis. Arterioscler Thromb Vasc Biol. 2009 Jan;29(1):61-6.

[127] Shintani S, Murohara T, Ikeda H, Ueno T, Sasaki K, Duan J, et al. Augmentation of postnatal neovascularization with autologous bone marrow transplantation. Circulation. 2001 Feb 13;103(6):897-903.

[128] Kamihata H, Matsubara H, Nishiue T, Fujiyama S, Tsutsumi Y, Ozono R, et al. Implantation of bone marrow mononuclear cells into ischemic myocardium enhances collateral perfusion and regional function via side supply of angioblasts, angiogenic ligands, and cytokines. Circulation. 2001 Aug 28;104(9):1046-52. 
[129] Kajiguchi M, Kondo T, Izawa H, Kobayashi M, Yamamoto K, Shintani S, et al. Safety and efficacy of autologous progenitor cell transplantation for therapeutic angiogenesis in patients with critical limb ischemia. Circ J. 2007 Feb;71(2):196-201.

[130] Kim SW, Han H, Chae GT, Lee SH, Bo S, Yoon JH, et al. Successful stem cell therapy using umbilical cord blood-derived multipotent stem cells for Buerger's disease and ischemic limb disease animal model. Stem Cells. 2006 Jun;24(6):1620-6.

[131] Zhang D, Jiang M, Miao D. Transplanted human amniotic membrane-derived mesenchymal stem cells ameliorate carbon tetrachloride-induced liver cirrhosis in mouse. PLoS One.6(2):e16789.

[132] Gaebel R, Furlani D, Sorg H, Polchow B, Frank J, Bieback K, et al. Cell origin of human mesenchymal stem cells determines a different healing performance in cardiac regeneration. PLoS One.6(2):e15652.

[133] Bi B, Schmitt R, Israilova M, Nishio H, Cantley LG. Stromal cells protect against acute tubular injury via an endocrine effect. J Am Soc Nephrol. 2007 Sep;18(9):2486-96.

[134] Imberti B, Morigi M, Tomasoni S, Rota C, Corna D, Longaretti L, et al. Insulin-like growth factor-1 sustains stem cell mediated renal repair. J Am Soc Nephrol. 2007 Nov;18(11):2921-8.

[135] Lu S, Lu C, Han Q, Li J, Du Z, Liao L, et al. Adipose-derived mesenchymal stem cells protect PC12 cells from glutamate excitotoxicity-induced apoptosis by upregulation of XIAP through PI3-K/Akt activation. Toxicology. Jan 11;279(1-3):189-95.

[136] Baregamian N, Song J, Jeschke MG, Evers BM, Chung DH. IGF-1 protects intestinal epithelial cells from oxidative stress-induced apoptosis. J Surg Res. 2006 Nov;136(1):31-7.

[137] Faiz M, Acarin L, Peluffo H, Villapol S, Castellano B, Gonzalez B. Antioxidant Cu/Zn SOD: expression in postnatal brain progenitor cells. Neurosci Lett. 2006 Jun 19;401(1-2):71-6.

[138] Hui L, Hong Y, Jingjing Z, Yuan H, Qi C, Nong Z. HGF suppresses high glucosemediated oxidative stress in mesangial cells by activation of PKG and inhibition of PKA. Free Radic Biol Med. Aug 1;49(3):467-73.

[139] Kida H, Yoshida M, Hoshino S, Inoue K, Yano Y, Yanagita M, et al. Protective effect of IL-6 on alveolar epithelial cell death induced by hydrogen peroxide. Am J Physiol Lung Cell Mol Physiol. 2005 Feb;288(2):L342-9.

[140] Kim WS, Park BS, Sung JH. The wound-healing and antioxidant effects of adiposederived stem cells. Expert Opin Biol Ther. 2009 Jul;9(7):879-87.

[141] Kim WS, Park BS, Park SH, Kim HK, Sung JH. Antiwrinkle effect of adipose-derived stem cell: activation of dermal fibroblast by secretory factors. J Dermatol Sci. 2009 Feb;53(2):96-102.

[142] Kim WS, Park BS, Kim HK, Park JS, Kim KJ, Choi JS, et al. Evidence supporting antioxidant action of adipose-derived stem cells: protection of human dermal fibroblasts from oxidative stress. J Dermatol Sci. 2008 Feb;49(2):133-42.

[143] Kim JH, Park SH, Park SG, Choi JS, Xia Y, Sung JH. The Pivotal Role of Reactive Oxygen Species Generation in the Hypoxia-Induced Stimulation of AdiposeDerived Stem Cells. Stem Cells Dev. Mar 2.

[144] Valle-Prieto A, Conget PA. Human mesenchymal stem cells efficiently manage oxidative stress. Stem Cells Dev. Dec;19(12):1885-93.

[145] Kasper G, Mao L, Geissler S, Draycheva A, Trippens J, Kuhnisch J, et al. Insights into mesenchymal stem cell aging: involvement of antioxidant defense and actin cytoskeleton. Stem Cells. 2009 Jun;27(6):1288-97. 
[146] Ho JH, Chen YF, Ma WH, Tseng TC, Chen MH, Lee OK. Cell Contact Accelerates Replicative Senescence of Human Mesenchymal Stem Cells Independent of Telomere Shortening and p53 Activation: Roles of Ras and Oxidative Stress. Cell Transplant. Dec 22.

[147] Ratajczak J, Wysoczynski M, Hayek F, Janowska-Wieczorek A, Ratajczak MZ. Membrane-derived microvesicles: important and underappreciated mediators of cell-to-cell communication. Leukemia. 2006 Sep;20(9):1487-95.

[148] Hugel B, Martinez MC, Kunzelmann C, Freyssinet JM. Membrane microparticles: two sides of the coin. Physiology (Bethesda). 2005 Feb;20:22-7.

[149] Herrera MB, Fonsato V, Gatti S, Deregibus MC, Sordi A, Cantarella D, et al. Human liver stem cell-derived microvesicles accelerate hepatic regeneration in hepatectomized rats. J Cell Mol Med. Jun;14(6B):1605-18.

[150] Gatti S, Bruno S, Deregibus MC, Sordi A, Cantaluppi V, Tetta C, et al. Microvesicles derived from human adult mesenchymal stem cells protect against ischaemiareperfusion-induced acute and chronic kidney injury. Nephrol Dial Transplant. Feb 15.

[151] Collino F, Deregibus MC, Bruno S, Sterpone L, Aghemo G, Viltono L, et al. Microvesicles derived from adult human bone marrow and tissue specific mesenchymal stem cells shuttle selected pattern of miRNAs. PLoS One.5(7):e11803.

[152] Parekkadan B, Milwid JM. Mesenchymal stem cells as therapeutics. Annu Rev Biomed Eng. Aug 15;12:87-117.

[153] Thirabanjasak D, Tantiwongse K, Thorner PS. Angiomyeloproliferative lesions following autologous stem cell therapy. J Am Soc Nephrol. Jul;21(7):1218-22.

[154] Klopp AH, Gupta A, Spaeth E, Andreeff M, Marini F, 3rd. Concise review: Dissecting a discrepancy in the literature: do mesenchymal stem cells support or suppress tumor growth? Stem Cells. Jan;29(1):11-9.

[155] Spaeth EL, Dembinski JL, Sasser AK, Watson K, Klopp A, Hall B, et al. Mesenchymal stem cell transition to tumor-associated fibroblasts contributes to fibrovascular network expansion and tumor progression. PLoS One. 2009;4(4):e4992.

[156] Sundin M, Orvell C, Rasmusson I, Sundberg B, Ringden O, Le Blanc K. Mesenchymal stem cells are susceptible to human herpesviruses, but viral DNA cannot be detected in the healthy seropositive individual. Bone Marrow Transplant. 2006 Jun;37(11):1051-9. 


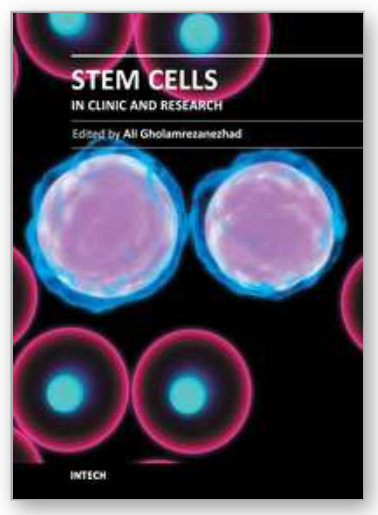

\author{
Stem Cells in Clinic and Research \\ Edited by Dr. Ali Gholamrezanezhad
}

ISBN 978-953-307-797-0

Hard cover, 804 pages

Publisher InTech

Published online 23, August, 2011

Published in print edition August, 2011

Based on our current understanding of cell biology and strong supporting evidence from previous experiences, different types of human stem cell populations are capable of undergoing differentiation or trans-differentiation into functionally and biologically active cells for use in therapeutic purposes. So far, progress regarding the use of both in vitro and in vivo regenerative medicine models already offers hope for the application of different types of stem cells as a powerful new therapeutic option to treat different diseases that were previously considered to be untreatable. Remarkable achievements in cell biology resulting in the isolation and characterization of various stem cells and progenitor cells has increased the expectation for the development of a new approach to the treatment of genetic and developmental human diseases. Due to the fact that currently stem cells and umbilical cord banks are so strictly defined and available, it seems that this mission is investigationally more practical than in the past. On the other hand, studies performed on stem cells, targeting their conversion into functionally mature tissue, are not necessarily seeking to result in the clinical application of the differentiated cells; In fact, still one of the important goals of these studies is to get acquainted with the natural process of development of mature cells from their immature progenitors during the embryonic period onwards, which can produce valuable results as knowledge of the developmental processes during embryogenesis. For example, the cellular and molecular mechanisms leading to mature and adult cells developmental abnormalities are relatively unknown. This lack of understanding stems from the lack of a good model system to study cell development and differentiation. Hence, the knowledge reached through these studies can prove to be a breakthrough in preventing developmental disorders. Meanwhile, many researchers conduct these studies to understand the molecular and cellular basis of cancer development. The fact that cancer is one of the leading causes of death throughout the world, highlights the importance of these researches in the fields of biology and medicine.

\title{
How to reference
}

In order to correctly reference this scholarly work, feel free to copy and paste the following:

Patricia Semedo, Marina Burgos-Silva, Cassiano Donizetti-Oliveira and Niels Olsen Saraiva Camara (2011). How do Mesenchymal Stem Cells Repair?, Stem Cells in Clinic and Research, Dr. Ali Gholamrezanezhad (Ed.), ISBN: 978-953-307-797-0, InTech, Available from: http://www.intechopen.com/books/stem-cells-in-clinicand-research/how-do-mesenchymal-stem-cells-repair-

\section{INTECH}

open science | open minds 


\section{InTech Europe}

University Campus STeP Ri

Slavka Krautzeka 83/A

51000 Rijeka, Croatia

Phone: +385 (51) 770447

Fax: +385 (51) 686166

www.intechopen.com

\section{InTech China}

Unit 405, Office Block, Hotel Equatorial Shanghai

No.65, Yan An Road (West), Shanghai, 200040, China

中国上海市延安西路65号上海国际贵都大饭店办公楼 405 单元

Phone: +86-21-62489820

Fax: $+86-21-62489821$ 
(C) 2011 The Author(s). Licensee IntechOpen. This chapter is distributed under the terms of the Creative Commons Attribution-NonCommercialShareAlike-3.0 License, which permits use, distribution and reproduction for non-commercial purposes, provided the original is properly cited and derivative works building on this content are distributed under the same license. 